Andrzej NIEGOLEWSKI, Maria MOLENDA, Wacław PIASZCZYŃSKI, Barbara RUSIN, Józef S'WINIARSKI

Economics

\title{
ECONOMICAL ASPECTS OF FISHERY MANAGEMENT ON ICNAF WATERS
} ASPEKTY EKONOMICZNE REGULACJI POŁOWÓW NA OBSZARZE ICNAF

\author{
Institute for Exploitation of Sea Resources of Agric. Acad. Szczecin; \\ Institute for Investigation of Market and Prices, Warsaw; \\ Sea Fisheries Institute, Gdynia
}

\begin{abstract}
The present study comprises an analysis of the interdependence of the fishing effort and effects of the Polish fishery on the ICNAF waters within the years 1963-1969. In the introductory chapters methods and econometric models applied are described, a particular attention being paid to the standardized measures of the fishing effort for various kinds of vessels operating on the ICNAF area. The sources of information, serving as a basis for the study are also presented. Subsequent chapters expose the seasonal character of fishery, its three forms, i.e., the seasonal character of fishing effort, fishing yields and fishing being discussed as well as their interrelationship. Results of the analysis are related to the ICNAF subdivision and the conclusion are drawn.
\end{abstract}

\section{INTRODUCTION}

The North-West Atlantic region comprised by the International Convention for N.W. Atlantic Fishery of 1949 signed and presently adhered to by 15 countries, tends to show distinct symptems of overfishing due to excessive exploitation of fish resources. To prevent the depletion of fish stocks to the extent which would cause the biological regeneration impossible, many protective means of management binding the member countrieshad been introduced in this region. So far the regulations have mainly been based on the determination of fishing gear selectivity. The catch quota, the closed seasons 
and closed areas, which have been introduced gradually since 1969, do not comprise those species of fish which are the main object of in erest of Polish fishery (haddock, silver hake, red turbot).

It may howewer be assumed that this is a transitory period only, as the tendencies towards the introduction of the catch quota embodying all the basic fish species, are irrevocable (cod, herring, Norway haddock, flatfish).

An imposition of restriction on the catches of the basic fish species will cause serious economical consequences for Polish fishery. The pertinent protective measures may apply to the limitation of the fishing mortality of fish stocks on the particular sub-regions and within determined time through:

- determination of catch quota for particular species

- restriction of fishing effort.

The realisation of each or any of such protective measures will call for the application of a modified system of operations of the fishing fleet. This wil consequently necessitate the introduction of determined structural and operational changes and will (basicaly) influence the course of its further development.

Owing to the lack of full substantial materials, no definite views have so far been formed among the Polish administration of fishery as to which control method may prove more beneficial for our fishery. So far, Poland's attitude to the question of fishery management has been based mainly on the results of biological investigations and statistical data.

According to the assumptions on the theory of fishing dynamics, the functional interrelation exist between the fishing effort and catch extent for given selectivity of fishing gear. This made it necessary to iniciate a study based on the comprehensive analysis of Polish fishery operations in Convention regions so as to make an opinion possible on the effectiveness of fishing and on its future organisation in this region.

\section{OBJECTIVE, METHOD AND MATERIAL}

Owing to the introduction of the first dispositions aimed at regulating the catches and in view of expected further regulations on ICNAF fishing grounds, it becames imperative to form the view on the actual state and effects of Polish fleet operations in this region. Before presenting the results of the study undertaken in this respect, attention should be drawn to the numerous factors which influence the effects of fishing operations. They include: seasonal character, population dynamics of particular fish species, alocation of fishing effort grounds of different yield during various seasons, type of fishing vessels and fishing methods and the technical progress. The interdependence of the above mentioned factors causes serious difficulties for methodical and statistical formulation of the subject. On the one hand the general conclusions call for generalization at a relatively high degree of aggregation, while on the other hand - the results of the study and the numerical data should be sufficiently detailed so as to enable the concretisation of the particular problems. 
It is necessary to point out that, the basic factor indispensable for determining the trends appering in the fishing process, is the seasonal character of fishing. This occurrence is, however, more complicated than currently accepted since it takes three forms:

The first form pertains to the seasonal character of fishing yields shaped by natural and cyclic fish concentration in determined regions. The second one is the seasonal character of fishing effort concentrated during certain periods on determined regions. The function of the seasonal character of fishing yields and of seasonal character of fishing effort is the third kind of seasonal character, i.e. the seasonal character of the extent of fishing and unloading commonly referred to as seasonal character of fishing.

Two aims were put down in the present study.

The first one is to indicate the method of the topic elaboration. The applied mathematical models and carried out estimates are opening the possibilities for further studies. They may be related to the particular sub-regions and be applicable for various fishing enterprises. The elaborated models and matematical programs will present the basis for the formulation of projection of catches in order to supplement the biological forecasts. Particularly it is of interest to note that the results of conducted trend estimate on interdependence of the fishing effort and of the yield fishing for the whole ICNAF region, compensated by the factor of seasonal character, may be considered as the verification for the Beverton model of eumetric catches.

The second task of the study was aimed at presenting an analysis of the effectivness of the Polish fishing fleet in the ICNAF region, which may serve as the basis for drawing conclusions as the policy of fishing operations.

Their results presented in this study were based on source data of dual kind. The data required for the formulation of the general longterm trends, should be more aggregated and should simultaneously comprise a sufficient time horizon which is indispensable for mathematical estimation. More detailed data should however be differentiated and referred to the particular elements, since they relate to shorter periods.

Therefore in order to determinate general longterm trends advantage was taken of the material published in the ICNAF annual "Statistical Bulletins" for the years of 1963-1968. As the time sequences for fishing ships in the group under 1800 GRT of Polish fishing fleet were in these materials not sufficiently long to establish these trends it was considered to, include in the calculations statistical data related to the group over 1800 GRT, what in respect of Poland comprises all the factory vessels. For the same reasons were left out the data relating to sub-region 6, whith in Polish catches had appeared sporadically up to 1968 .

The data applied show the fishing effort expressed in fishing days. In order to carry out adifferential analysis for the particular elements it became necessary to call for more specific and exact material. Such source of material proved to the ship's logbooks and the so-called master's excepts from all the vessel types operating during 1966-1969 on all ICNAF sub-regions, based on annual and monthly periods. The collected statistics comprise the extene of catches in full relation with the distribution for particular fish species, nominal trawling hours and determination of fishing gear. As regards to the range 
of costs and the value of catches, use was made of financial documents accessible in fishery for the years of 1968-1969 pertaining to the annual accounts for each type of vessel. To make the comparisons the stipulated overall costs were decreased by the value of crew renumeration. The value of unloaded fish at market prices was taken as the value of the catch.

To compare the fishing effort of the particular types of vessels, an attempt was made to apply the unified unit as comparative measurement of fishing effort expressed by one hour of trawling. In this connection were introduced the corrective coefficients, such as type of ship, fishing gear and kind of fish. A detailed description of the method for determination of a unified unit is contained in the annex.

The fishing system applicable in Polish fishing were divided into three groups

1. Fishing system with otter trawl for herring and mackerel fishing.

2. Fishing system with otter trawl for cod fishing.

3. Fishing system with mid-water trawls.

In the first group, for $100 \%$ of relative fishing capacity per one hour of trawling at the determined parameters of most frequently used trawls, the ships B-15 and B-29 were taken whilst assuming the following correcting coefficients for the ramaining ships:

$$
\begin{array}{lll}
\text { B-10 and B-14 - 54.7 } & \text { B-23 }-89.1 \\
\text { B-20 - 72.2 } & \text { B-18 }-95.7
\end{array}
$$

Within the second group, taking the same ships (B-15, B-22, B-29) at the determined parameters of trawls most frequently used and assuming for $100 \%$ of relative fishing capacity per one hour of trawl, the following correcting coefficients were assumed for the ramaining ships.

$$
\begin{array}{lrl}
\text { B-10 and B-14 }-61.0 & \text { B-23 }-73.0 \\
\text { B-20 } & -70.0 & \text { B-18 }-94.1
\end{array}
$$

Within the third group, the ships B-15 and B-22 were assumed for $100 \%$ of relative fishing capacity for determined parameters of trawls most frequently used, and the following correcting coeficients for the remaining ships determined,

$$
\begin{array}{lll}
\text { B-10 and B-14 } & -64.1 & \text { B-18 }-93.9 \\
\text { B-20 } & -70.0 & \text { B-29 }-103.0
\end{array}
$$

$$
\text { B-23 - } 93.9
$$

The application of the above mentioned correcting coefficients permitted a comparative convertion of fishing effort of each type of vessel measured in trawling hours and made it possible to express it in unified units. Thus the conception of a unified trawling hour as a measurement of the effort was used in this work. It presents a trial that has not. yet been applied so far in any existing similar elaboration, and though not free of the estimation error, still permits to draw comparisons of effort for the various vessel types and fishing gear respectively.

Applying unified units of fishing effort by way of recalculating, comparative outputs reached on particular sub-regions and for all types of vessels and enterprises for years 1966-1969 were obtained.

Summary statement comprises all ICNAF regions divided into sub-regions and years. 
The costs which were assumed as fixed for the particular sub-regions were determined by calculation of the average one hour trawling costs in unified units for all ICNAF regions and the result related to the number of trawling hours separately for each type of ship.

The costs obtained for each sub-region permitted to determine the cost of one ton of fish (live weight) relating to sub-region, type of vessel and enterprise.

The material thus prepared permitted to follow-up computations and to make an analysis of the effects obtained in the years of 1968-1969, i.e. for calculation of the costs of fishing effort, one ton of fish in live weight and of also to compute the output related to the unified unit of fish effort on all the sub-regions with division into month and seperately for each type of ship, with division into sub-regions.

The results have been complied in comprehensive arrangement in relation to the whole ICNAF region.

For investigating the statistical analysis method was applied ommiting the descriptions related to the matter generally known either in relation to the definitions of fishing economics or to the method of the statistical analysis applied.

The inicial source data with the full document materials can be found at the Department Fish Economics Agriculture Academy Szczecin.

\section{PROBLEM OF SEASONAL CHARACTER}

As mentioned previously, the conception of seasonal character in terms of economical category cannot be limited to the usally accepted term of fishing season. Subjected to analysis of seasonal character are its three forms: the seasonal character of fishing effort, seasonal yield and seasonal volume of catches derived from them.

Owing to the fact that an analysis of seasonal character requires relatively long time series, for the calculations were used only the data referred to the general longiterm trends with the exception of the B-11 and B-14 ships. For these types of vessels statistical data did not possess the time series of a suitable length. For the same reasons it was not possible to derive any coefficients of seasonal character for the particular sub-regions of Polish fishery.

The analysis for all the forms of seasonal character and their factors in the Polish fishery is based on the fishing activity of vessels above 1800 GRT (all factory vessels) and on the average data for the total ICNAF Region for the years of 1963-1968. Nevertheless the results of analysis are substantially representative because they comprise more than $80 \%$ of the total Polish catches for that period.

For the determination of the seasonal character appearing in all above mentioned forms, the following multiplicative model was assumed:

$$
Y_{t}=C_{t} \cdot S_{t^{\prime}} \cdot I_{t}
$$

where:

$\mathrm{t}=$ the value of time series during the time $\mathrm{t}$;

$c_{t}=$ the value of trend during the time $t$; 
$\mathrm{S}_{\mathrm{t}}=$ factor of seasonal character during the time $\mathrm{t}$;

$l_{t}=$ the value of random component during the time $t$.

To determine the factor of seasonal character expressed by the value $S_{t}$ assumed an accordance of constant seasonal character for the particular years. Such assumptions were verified by smoothing the time series and thereafter calculated:

- moving average for 12 month;

- relative fluctuations of seasonal character;

- the variances of relative seasonal fluctuations;

- the factors of seasonal character;

- the value of smoothed series.

Basing on the smoothed series a hypothesis on appearance of linear trend was presented and estimation was made:

$$
C_{t}=a \cdot t+b
$$

After the verification of the trend, the searched model of seasonal character is presented as:

$$
\mathrm{Y}_{12 \mathrm{rtm}}=\mathrm{a}(12 \mathrm{r}+\mathrm{m})+\mathrm{b} \mathrm{S}_{\mathrm{m}}
$$

where:

$\mathrm{r}=$ consecutive

$\mathrm{m}=$ number of month in the given year (from 1 to 12 ).

The above presented model was applied to characterise the interrelations of the seasonal fishing effort (in fishing days), seasonal output (in tons per fishing day), and the seasonal character of catches for Polish fishing fleet comprising the factory type of vesse? over 1800 GRT operating on the entire ICNAF region.

The background data based on the statistical data mentioned in chapter 1 and the smoothed for 12 months moving average data are presented respectively in Tables 1,2 and 3 , while the corrective for the seasonal character of fishing effort, output and of catches, in Table 4. Basing on data of table 4, the curve of trend was elaborated and presented on Fig. 1.

An interpretation of the comparison results of the trend factors for the seasonal character of marine fisheris in the years of 1963-1968 in relation to the effort and output, indicates a faulty alocation of Polish fishing efforts on ICNAF, resulting from relatively low fishing effort during the high yield seasonsand on increase tendency to it during the seasons of lower output.

Second characteristic occurrence is a convergent direction of trends for the catch and which indicates to a distinctly higher correlation between the extent of fishing and the yield than between the extent of fishing and fishing effort.

To examine the interdependence between the fishing effort and the yield and the extent of fishing in 1969 for all Polish catches on ICNAF Region, an analysis was made on the basis of the details mentioned in chapter 1 , on page 88 in which the fishing effort and the yield per one trawling hour of all types of ships are expressed in uniformed trawling hours. The calculations relate to one year and therefore cannot comprise the 
Seasonal character of fishing effort of Polish factory fleet in ICNAF region for the years 1963-1968 (fishing days)

(assumed arrangement)

\begin{tabular}{|c|c|c|c|c|c|c|c|c|c|c|c|c|}
\hline & \multicolumn{12}{|c|}{ months } \\
\hline years & I & II & III & IV & V & VI & VII & VIII & IX & $\mathrm{X}$ & $\mathrm{XI}$ & XII \\
\hline 1963 & 24.0 & 54.0 & 61.0 & 91.0 & 110.0 & 50.0 & 135.0 & 113.0 & 47.0 & 55.0 & 59.0 & 50.0 \\
\hline 1964 & 113.0 & 136.0 & 97.0 & 88.0 & 140.0 & 143.0 & 145.0 & 131.0 & 141.0 & 140.0 & 82.0 & 95.0 \\
\hline 1965 & 154.0 & 151.0 & 118.0 & 152.0 & 203.0 & 216.0 & 223.0 & 274.0 & 216.0 & 143.0 & 38.0 & 160.0 \\
\hline 1966 & 189.0 & 222.0 & 206.0 & 258.0 & 222.0 & 197.0 & 233.0 & 209.0 & 231.0 & 184.0 & 252.0 & 279.0 \\
\hline 1967 & 295.0 & 260.0 & 287.0 & 266.0 & 326.0 & 252.0 & 263.0 & 236.0 & 380.0 & 341.0 & 305.0 & 269.0 \\
\hline 1968 & 325.0 & 357.0 & 488.0 & 352.0 & 469.0 & 415.0 & 361.0 & 402.0 & 379.0 & 400.0 & 318.0 & 408.0 \\
\hline
\end{tabular}

(corrected arrangement)

\begin{tabular}{|c|c|c|c|c|c|c|c|c|c|c|c|c|}
\hline 1963 & 22.8 & 51.9 & 59.4 & 97.8 & 93.8 & 47.1 & 115.7 & 101.9 & 43.2 & 64.2 & 80.8 & 66.0 \\
\hline 1964 & 107.4 & 130.6 & 94.5 & 94.6 & 118.3 & 134.7 & 124.3 & 118.2 & 129.7 & 163.5 & 112.3 & 125.4 \\
\hline 1965 & 146.4 & 145,0 & 115.0 & 163.4 & 171.6 & 203.5 & 191.1 & 247.2 & 198.7 & 167.0 & 52.0 & 211.3 \\
\hline 1966 & 179.7 & 213.2 & 200.7 & 277.3 & 187.7 & 185.6 & 199.1 & 188.6 & 212.5 & 214.9 & 345.0 . & 368.4 \\
\hline 1967 & 280.5 & 249.7 & 279.6 & 285.9 & 275.6 & 237.4 & 225.4 & 212.9 & 349.6 & 398.3 & 417.5 & 355.2 \\
\hline 1968 & 309.0 & 342.8 & 475.5 & 378.4 & 396.5 & 391.0 & 309.4 & 362.7 & 348.7 & 467.2 & 435.3 & 538.7 \\
\hline
\end{tabular}


Seasonal character of fishing efficiency of Polish factory fleet in ICNAF region years 1963-1968 (tons)

(assumed arrangement)

\begin{tabular}{|c|c|c|c|c|c|c|c|c|c|c|c|c|}
\hline \multirow[b]{2}{*}{ years } & \multicolumn{12}{|c|}{ months } \\
\hline & $\mathbb{I}$ & II & III & IV & $\mathbf{V}$ & VI & VIII & VIII & $\mathbb{I X}$ & $X$ & XI & XII \\
\hline 1963 & 26.3 & 37.1 & 30.0 & 33.5 & 31.8 & 20.1 & 24.5 & 29.8 & 20.6 & 19.8 & 21.5 & 18.0 \\
\hline 1964 & 29.8 & 32.9 & 25.4 & 23.8 & 28.8 & 27.9 & 25.3 & 23.6 & 21.9 & 15.1 & 20.6 & 30.0 \\
\hline 1965 & 42.6 & 34.2 & 35.7 & 36.2 & 25.8 & 14.7 & 17.7 & 16.8 & 23.5 & 21.7 & 12.6 & 27.9 \\
\hline 1966 & 42.8 & 39.9 & 29.3 & 28.1 & 26.6 & 16.7 & 23.2 & 30.9 & 27.8 & 20.1 & 16.1 & 23.4 \\
\hline 1967 & 30.2 & 31.2 & 26.8 & 22.2 & 33.8 & 18.0 & 17.3 & 21.3 & 20.9 & 22.2 & 18.8 & 34.5 \\
\hline 1968 & 36.4 & 56.7 & 37.0 & 33.1 & 27.8 & 24.5 & 17.3 & 21.9 & 29.6 & 16.2 & 17.5 & 26.4 \\
\hline
\end{tabular}

(corrected arrangement)

\begin{tabular}{|c|c|c|c|c|c|c|c|c|c|c|c|c|}
\hline 1963 & 19.2 & 26.5 & 25.6 & 31.8 & 30.0 & 27.0 & 28.9 & $3: 1.0$ & 24.2 & 24.7 & 31.4 & 17.0 \\
\hline 1964 & 21.8 & 23.5 & 21.7 & 22.6 & 27.1 & 37.5 & 29.9 & 24.6 & 25.7 & 18.8 & 30.1 & 28.4 \\
\hline 1965 & 31.1 & 24.4 & 30.5 & 34.4 & 24.3 & 19.8 & 20.9 & 17.5 & 27.6 & 27.1 & 18.4 & 26.4 \\
\hline 1966 & 31.3 & 28.5 & 25.0 & 26.7 & 25.1 & 22.4 & 27.4 & 32.2 & 32.7 & 25.1 & 23.5 & 22.2 \\
\hline 1967 & 22.1 & 22.3 & 22.9 & 21.1 & 31.8 & 24.2 & 20.4 & 22.2 & 24.6 & 27.7 & 27.4 & 32.7 \\
\hline 1968 & 26.6 & 40.5 & 31.6 & 31.4 & 26.2 & 32.9 & 20.4 & 22.8 & 34.8 & 20.2 & 25.5 & 25.0 \\
\hline
\end{tabular}


Seasonal character of yield of Polish factory fleet in ICNAF region for the years 1963-1968 (tons per fishing day)

(assumed arrangement)

\begin{tabular}{|c|c|c|r|r|r|r|r|r|r|r|r|r|}
\hline & \multicolumn{10}{|c|}{ years } & I & \multicolumn{10}{|c|}{ II } & III & IV & V & VI & VII & VIII & IX & X & XI & XII \\
\hline 1963 & 632.0 & 2003.0 & 1835.0 & 3051.0 & 3535.0 & 1006.0 & 3308.0 & 3370.0 & 970.0 & 1087.0 & 1269.0 & 900.0 \\
1964 & 3370.0 & 4481.0 & 2461.0 & 2090.0 & 4038.0 & 3993.0 & 3672.0 & 3094.0 & 3082.0 & 2119.0 & 1693.0 & 2852.0 \\
1965 & 6568.0 & 5157.0 & 4210.0 & 5499.0 & 5246.0 & 3180.0 & 3938.0 & 4615.0 & 5070.0 & 3109.0 & 478.0 & 4471.0 \\
1966 & 8084.0 & 8865.0 & 6041.0 & 7256.0 & 5905.0 & 3281.0 & 5412.0 & 6464.0 & 6429.0 & 3702.0 & 4065.0 & 6530.0 \\
1967 & 8920.0 & 8104.0 & 7705.0 & 5900.0 & 11022.0 & 4544.0 & 4546.0 & 5027.0 & 7931.0 & 7572.0 & 5724.0 & 9293.0 \\
1968 & 11818.0 & 20232.0 & 18044.0 & 11661.0 & 13042.0 & 10159.0 & 6234.0 & 8796.0 & 11.200 .0 & 6479.0 & 5557.0 & 10752.0 \\
\hline
\end{tabular}

(corrected arrangement)

\begin{tabular}{|r|r|r|r|r|r|r|r|r|r|r|r|r|}
\hline 1963 & 453.0 & 1292.5 & 16616 & 2847.1 & 2797.7 & 1316.7 & 3397.4 & 3400.3 & 1034.0 & 1815.9 & 2461.8 & 1078.4 \\
1964 & 2415.3 & 2891.5 & 2228.5 & 1950.3 & 3195.7 & 5226.4 & 3771.2 & 3121.8 & 3285.3 & 3539.9 & 3284.3 & 3417.5 \\
1965 & 4707.4 & 3327.7 & 3812.2 & 5131.5 & 4151.8 & 4162.3 & 40.44 .4 & 4656.4 & 5404.5 & 5193.7 & 927.3 & 5357.5 \\
1966 & 5793.9 & 5720.5 & 5470.2 & 6771.1 & 4673.3 & 4294.5 & 5558.2 & 6522.0 & 6853.1 & 6184.3 & 7885.9 & 7824.7 \\
1967 & 6303.1 & 5229.4 & 6977.0 & 5505.8 & 8723.0 & 5947.6 & 4667.8 & 5072.1 & 8454.2 & 12649.3 & 11104.3 & 11135.6 \\
1968 & 8470.1 & 13055.4 & 16339.1 & 10881.8 & 10321.7 & 6402.4 & 8875.0 & 11938.9 & 10938.9 & 10823.4 & 10780.3 & 12883.8 \\
\hline
\end{tabular}




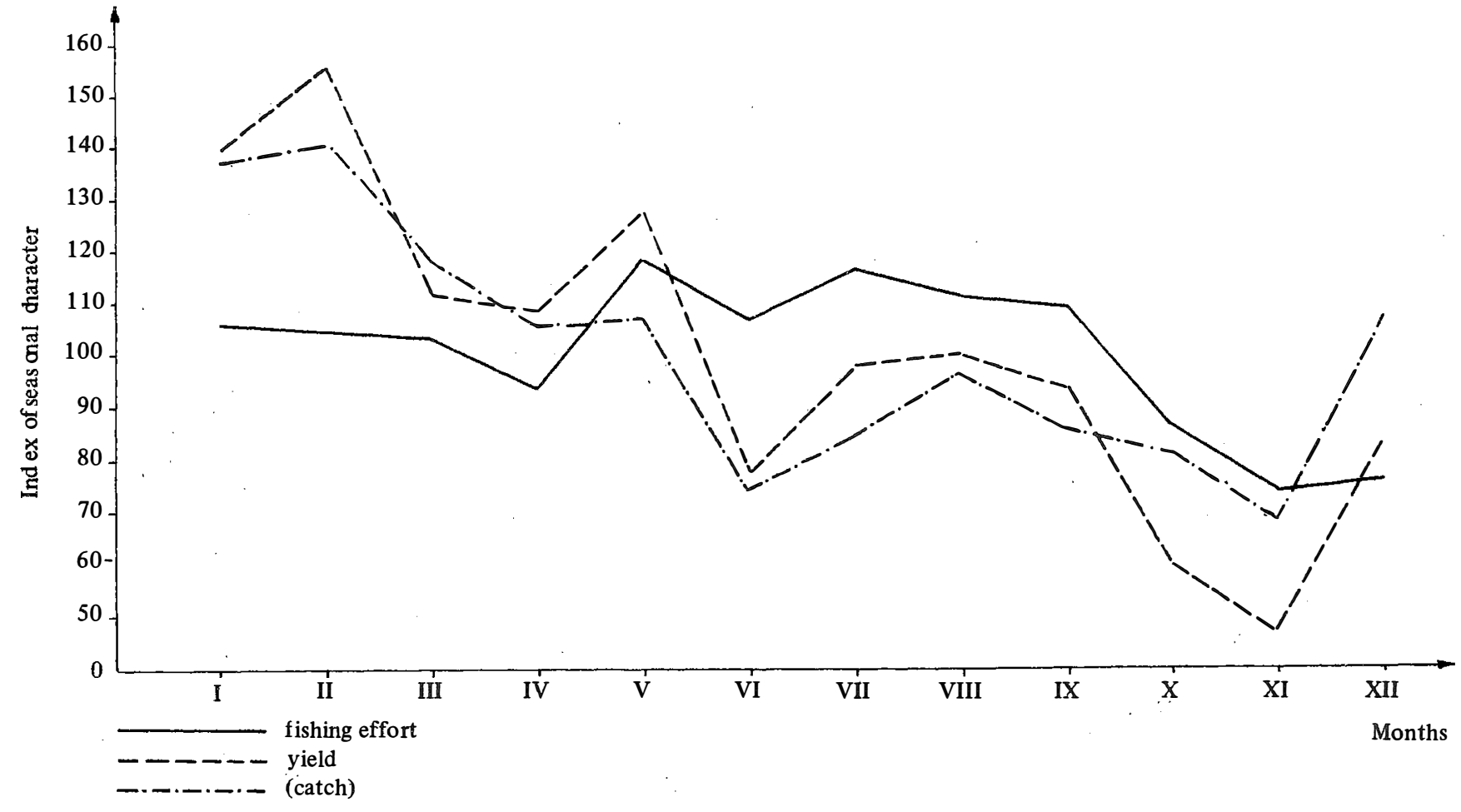

Fig. 1. Indexes for seasonal character of fishing effort of Polish factory fleet in ICNAF region for the years $1963-1968$ 
Indexes for seasonal character of fishing effort (catch)

and of yield of Polish factory fleet in ICNAF region for the years 1963-1968

\begin{tabular}{|c|c|c|c|c|c|c|c|c|c|c|c|c|}
\hline \multirow[b]{2}{*}{$\begin{array}{l}\text { Seasonal } \\
\text { character }\end{array}$} & \multicolumn{12}{|c|}{ months } \\
\hline & I & II & III & IV & V & VI & VII & VIII & IX & $\mathrm{X}$ & XI & XII \\
\hline $\begin{array}{l}\text { Fishing } \\
\text { effort }\end{array}$ & 105.2 & 104.1 & 102.6 & 93.0 & 118.3 & 106.1 & 116.7 & 110.8 & 108.7 & 85.6 & 73.0 & 75.7 \\
\hline Yield $^{2}$ & 136.8 & 140.0 & 117.2 & 105.3 & 106.1 & 74.4 & 84.7 & 96.0 & 85.1 & 80.2 & 68.5 & 83.5 \\
\hline $\begin{array}{l}\text { Output } \\
\text { (catch/tons) }\end{array}$ & 139.5 & 155.0 & 110.4 & 107.2 & 126.4 & 76.4 & 9.7 .4 & 99.1 & 93.8 & 59.9 & 51.5 & 105.6 \\
\hline
\end{tabular}

1 unified trawling hours

2 tons per unified trawling hour 
Fishing effort, output (catch) and fishing yield of Polish factory fleet in ICNAF region for particular menths of 1969

(assumed arrangement)

\begin{tabular}{|c|c|c|c|c|c|c|c|c|c|c|c|c|}
\hline \multirow[b]{2}{*}{ Particulars } & \multicolumn{12}{|c|}{ months } \\
\hline & I & III & III & IV & V & VII & VII & VIII & IX & $\mathrm{X}$ & XI & XII \\
\hline $\begin{array}{l}\text { Fishing } \\
\text { effort }^{1}\end{array}$ & 5320.3 & 8802.5 & 7850.9 & 6020.7 & 9547.6 & 8868.6 & 6407.7 & 6605.9 & 9128.1 & 6329.8 & 5087.3 & 4178.4 \\
\hline $\begin{array}{l}\text { Output } \\
\text { (tons/catch) }\end{array}$ & 15968.6 & 29227.5 & 23124.8 & 15028.9 & 18969.5 & 12403.7 & 8351.9 & 8431.3 & 14795.4 & $11076: 5$ & 11339.6 & 8805.8 \\
\hline Yield $^{2}$ & 3.00 & 3.32 & 2.95 & 2.50 & 1.99 & 1.40 & 1.30 & 1.28 & 1.62 & 1.75 & 2.23 & 2.11 \\
\hline
\end{tabular}

(corrected arrangement)

\begin{tabular}{|l|r|r|r|r|r|r|r|r|r|r|r|r|r|}
\hline $\begin{array}{l}\text { Fishing } \\
\text { effort }\end{array}$ & 5320.3 & 7324.6 & 7558.0 & 7806.4 & 8145.6 & 8274.9 & 7294.0 & 7380.0 & 7354.6 & 6848.7 & 5198.5 & 4178.4 \\
$\begin{array}{l}\text { Output } \\
\text { (tons/catch) }\end{array}$ & 15968.6 & 22773.6 & 22460.4 & 19041.0 & 15467.3 & 132441.7 & 9728.0 & 10526.2 & 11434.4 & 12070.5 & 10495.0 & 8805.8 \\
Yield $^{2}$ & 3.00 & 3.09 & 2.92 & 2.48 & 1.96 & 1.56 & 1.32 & 1.40 & 1.55 & 1.86 & 2.03 & 2.11 \\
\hline
\end{tabular}

1 unified trawling hours

2 tons per unified trawling hour 


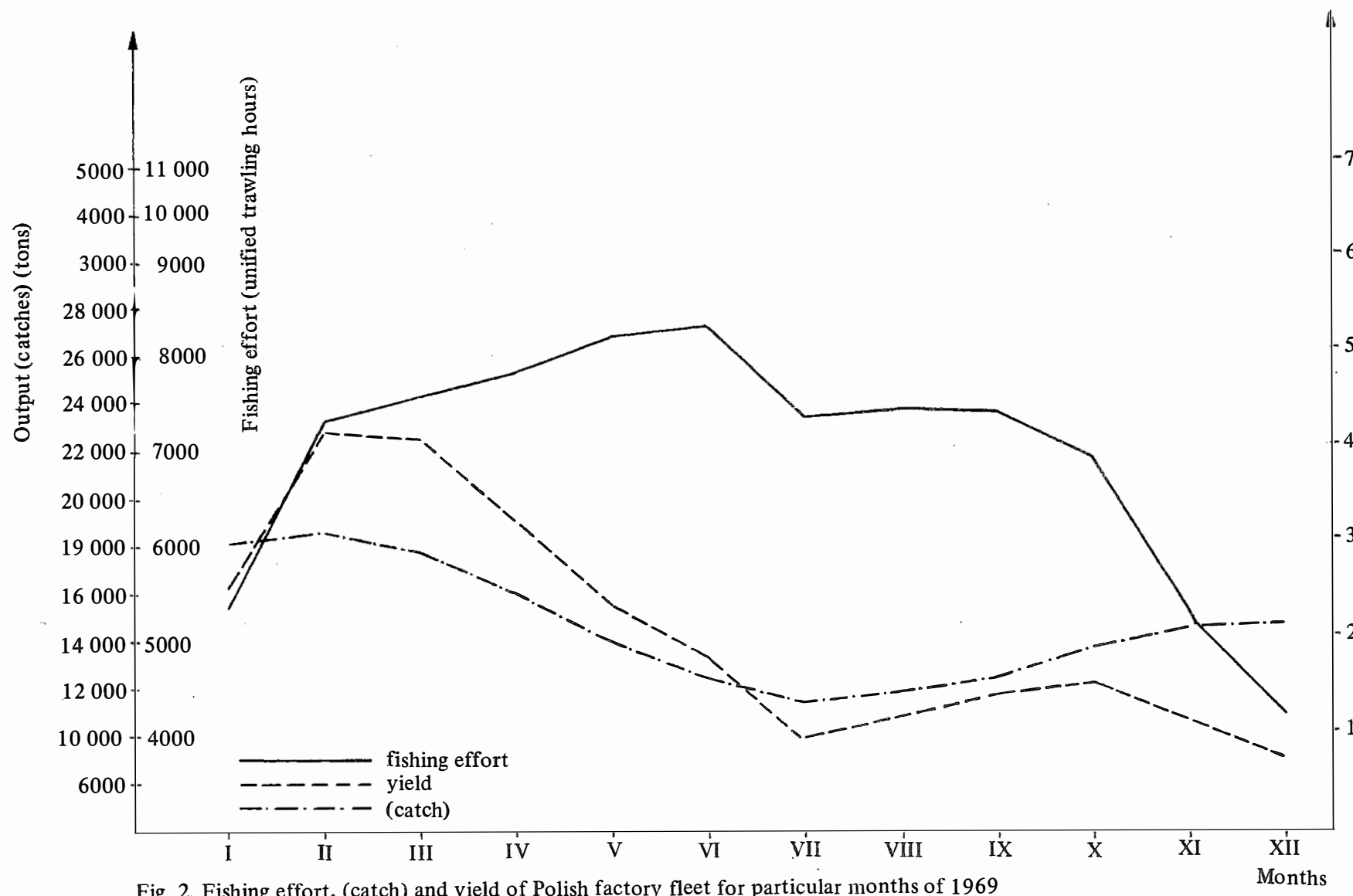

Fig. 2. Fishing effort, (catch) and yield of Polish factory fleet for particular months of 1969 (assumed arrangement) 
factor of seasonal character, but in turn comprise all Polish catches, i.e. all types of Polish vessels operating on ICNAF waters during 1969. The original and the smoothed series for the efforts and fishing output are presented in Table 5.

The data of the smoothed series are graphically presented on Fig. 2. In spite of some imperfection of the accepted method for elaboration of 1969, the curves representing the efforts, yield and catches of fishing in monthly arrangement run similiarly to the factor trends of seasonal character for the years of 1963-1968; this indicates to the stabilization of the fishing policy and the lack of changes in ways of exploitation of ICNAF fishing grounds towards better use of the output seasons.

\section{INTERDEPENDENCE OF EFFORTS AND EXTENT OF FISHING}

An interdependence between the increase of fishing effort and the increase of fishing yield as well as formation of marginal increases was examined by the production function in relation to the efforts:

$$
\mathrm{Y}=\mathrm{Ax} \mathrm{Ai}^{\mathrm{A}}
$$

The assumed production function was obtained by estimation acc. to data of smoothed series presented in Table 1 and 3 in the form of:

$$
\mathrm{Y}=161.8509 \times 0.6546 \quad \mathrm{R}=0.843
$$

where:

$$
\begin{aligned}
& \mathrm{Y}=\text { yield of fishing (tons) } \\
& \mathrm{X}=\text { fishing effort (Fishing days); }
\end{aligned}
$$

and it was ascertained that the increments of the function are decreasing with the increase of effort. Graphically the function was drawn basing upon data of table 1 and 3 as presented by Fig. 3 .

The course of the fishing function in relation to the increase of the fishing effort for Polish fishery on the entire ICNAF region up to 1968 corresponds fully to the assumptions of asymptotic curve of fishing yield from which is evident, that while increasing the intensity of fishing, the rate of growth for fishing extent is decreasing and the final increases are getting lower.

However, the course of curve up to 1968 does not permit to conclude, whether asymptotic shape reached in 1968 the maximum level of the constant yields estimated as average for total ICNAF region.

The yields for some sub-regions of ICNAF decreased considerably in 1969 and 1970. Therefore, the presented calculus for interdependance of the fishing and the effort was supplemented after the termination of the study with the data published of ICNAF Statistical Bulletin 1969 and with the data of 1970 from the international statistics of Sea Fisheries Institute. The supplement comprises also an inclusion of data relating to the sub-region 6 . Thus the calculus of interdependance between the increase of fishing effort and the increase of fishing yield and formulation of marginal increases 


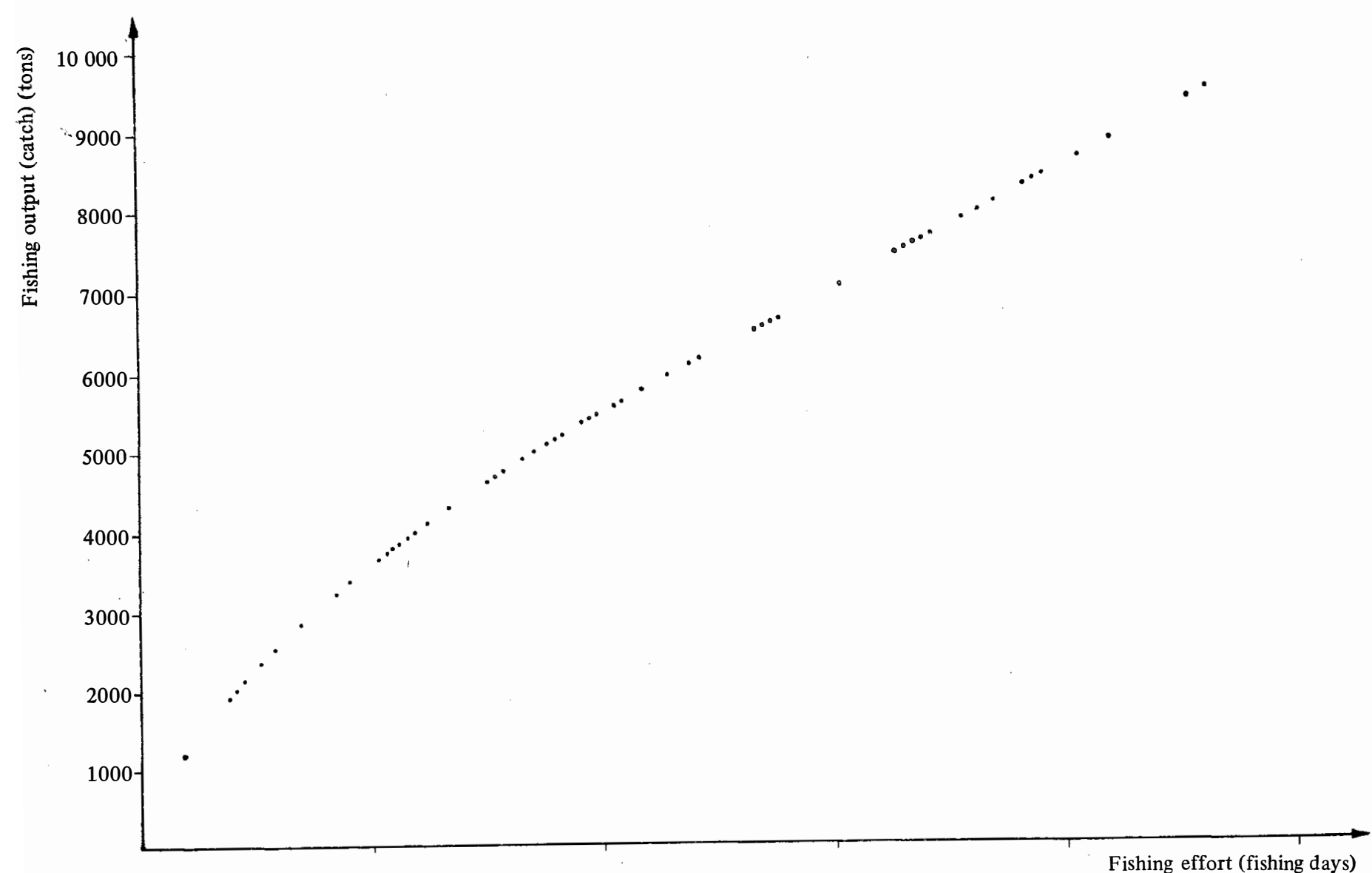


were based on the data relating to the entire ICNAF region for 1963-1970 for Polish fishery operating with ships over 1800 GRT.

Basing on the above data, the square binomial was estimated and the following function was obtained:

$$
y=0.0133^{2}+32.3974 x-426.8135
$$

where:

$$
\begin{aligned}
& \mathrm{y}=\text { yield of fishing (tons) } \\
& \mathrm{x}=\text { fishing effort (fishing days). }
\end{aligned}
$$

The function presents the interdependence of catches and effort obtained by the smoothed series i.e. after elimination of fluctuations, and the values obtained on the curve do not correspond to the empiric values but to the values of the smoothed series.

Owing to its negative coefficient, the function at $x^{2}$ possesses the course given on Fig. 4.

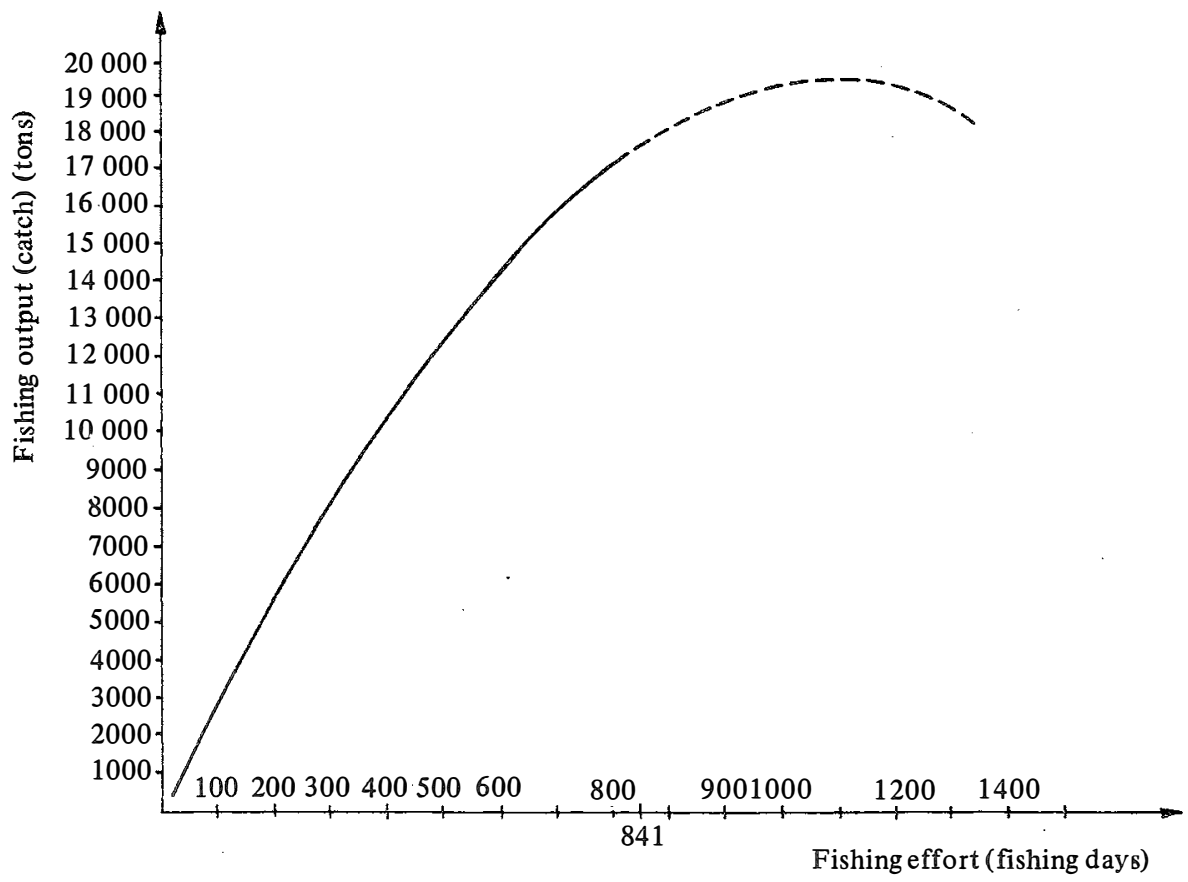

Fig. 4. Interrelation of fishing effort and output (catch) of Polish factory fleet in ICNAF region for years $1963-1970$

As it appears from comparison of both figures, the course of function of Fig. 4 distinctly differs to the previous (Fig. 3). While the course of function presented on Fig. 3 possesses the tendency to asymptotic course, the same presented on Fig. 4 indicates the decreasing trend after passing the maximum. Such shaping of function was influenced by the fishing results of 1969 and 1970 during which occured the well known output decreases for certain sub-regions. 
In total of the Polish fishing in ICNAF region, no maximum possibility was obtained up to 1970; this, however, does not exclude that such possibilities were already attained on certain sub-regions or in relation to certain species of fish. To form the average picture of the situation for the total ICNAF region, contributed the mutual substitutions of the various fish species and their different fishing outputs for the particular sub-regions for the total period studied.

\section{FISHING EFFORTS AND EFFECTS IN YEARS 1966-1969 OF THE PARTICULAR TYPES OF SHIP OF THE POLISH FACTORY FLEET ON ICNAF REGION}

The effectiveness of the Polish fishing fleet on ICNAFF region for the years of 1966-1969 was analysed acc. to data presented in part I on p. 103 in relation to the particular types of ships. Subjected to analysis were the fishing effort expressed in uniformed units per 1 hour of trawling, the catches presented in tons and the presented in unified units of fishing effort, all obtained by the particular ship types on the $6^{\text {th }}$ subregion of ICNAF.

The data distributed in relation to the enterprises are presented in enclosures 1-3; while the summary list of average data for total ICNAF region for the particular years is presented in Table 6.

During the analysed period the fishing effort increased very quickly, assuming 1966 as the 100. the increase of fishing effort for the years of 1967-1969 raised to 185,264 and 281 respectively. The highest average participation in fishing effort, exceeding $60 \%$, in that period had the ships B-15, while for the ships B-20, B-10/14 and B-18 same were placed below $10 \%$. The ships B-20, B-22 and B-29 participated in about $2 \%$ each (Tab. 7).

The increase was also noted in relation to the catches. But, in comparison with fishing effort, the highest fishing output prevailed for 1968. Assuming again 1966 for 100, the effort index for the years 1967-1969 amounted to 164, 275 and 246.

From the comparison of the presented dynamics of fishing effort and of dynamics of fishing, the increase of catches in 1969 was not in corresponding relation to the increase of fishing effort.

The values given in Table 7 indicate that there is no correlation between the participation of particular ship types in fishing effort and in their catches. This was due to the different output per 1 hour of trawling as presented in the uniformed units and obtained by particular types of ship. The average fishing output for the unified umit in the investigated period mounted to $2.04 \mathrm{t}$ with the highest value obtained in 1968 . The decrease of output in 1969 comprised all the types of vessels with exeption of the type B-22 (Tab. 6).

Subjected to further analysis was the relation of fishing effort and catches acc. to ship types for the years of 1968 and 1969 for the particular sub-regions.

The analysis comprises the calculus of the cost per $1 \mathrm{hr}$ of trawling, of cost per 1 ton of catches in full relation and of output acc. to the data presented in enclosures 5-11. The 
Fishing effert, output (catch) and yield of Polish factory fleet in ICNAF region for years 1966-1969

(according to types of ships)

\begin{tabular}{|c|c|c|c|c|c|c|c|c|c|c|c|c|}
\hline \multirow[b]{2}{*}{ years } & \multicolumn{3}{|c|}{ B-15 } & \multicolumn{3}{|c|}{ B-22 } & \multicolumn{3}{|c|}{ B-10/14 } & \multicolumn{3}{|c|}{ B-18 } \\
\hline & $\begin{array}{l}\text { fishing } \\
\text { effort }^{1}\end{array}$ & $\begin{array}{l}\text { output } \\
\text { (catch) } \\
\text { (tons) } \\
\end{array}$ & yield $^{2}$ & $\begin{array}{l}\text { fishing } \\
\text { effort }\end{array}$ & $\begin{array}{l}\text { output } \\
\text { (catch) } \\
\text { (tons) }\end{array}$ & yield & $\begin{array}{l}\text { fishing } \\
\text { effort }\end{array}$ & $\begin{array}{l}\text { output } \\
\text { (catch) } \\
\text { (tons) }\end{array}$ & yield & $\begin{array}{l}\text { fishing } \\
\text { effort }\end{array}$ & $\begin{array}{l}\text { output } \\
\text { (catch) } \\
\text { (tons) } \\
\end{array}$ & yield \\
\hline 1966 & 26936.1 & 67771.0 & 2.34 & - & - & - & - & - & - & 977.6 & 4396.0 & 4.49 \\
\hline 1967 & 42394.4 & 82917.7 & 1.96 & - & - & - & 2493.5 & 4605.7 & 18.5 & 596.0 & 1664.2 & 2.79 \\
\hline 1968 & 45072.8 & 106690.7 & 2.37 & 2244.8 & 5361.7 & 2.39 & 8581.4 & 21403.7 & 2.49 & 6238.0 & 20690.0 & 3.81 \\
\hline 1969 & 42004.8 & 91352.3 & 2.17 & .2545 .4 & 7244.4 & 2.38 & 10635.8 & 14975.6 & 1.4 & 7681.0 & 22808.3 & 2.97 \\
\hline $66-69$ & 158308.1 & 348732.0 & 2.20 & 4790.2 & 12606.1 & 2.63 & 2170.5 & 40985.0 & 1.89 & 1549.6 & 49559.1 & 3.20 \\
\hline
\end{tabular}

\begin{tabular}{|c|c|c|c|c|c|c|c|c|c|c|c|c|c|c|c|}
\hline \multirow[b]{2}{*}{ years } & \multicolumn{3}{|c|}{ B-20 } & \multicolumn{3}{|c|}{ B-23 } & \multicolumn{3}{|c|}{ B-14 } & \multicolumn{3}{|c|}{ B-29 } & \multicolumn{3}{|c|}{ Razem } \\
\hline & $\begin{array}{l}\text { fishing } \\
\text { effort }\end{array}$ & $\begin{array}{l}\text { output } \\
\text { (catch) } \\
\text { (tons) }\end{array}$ & yield & $\begin{array}{l}\text { fishing } \\
\text { effort }\end{array}$ & $\begin{array}{l}\text { output } \\
\text { (catch) } \\
\text { (tons) }\end{array}$ & yield & $\begin{array}{l}\text { fishing } \\
\text { effort }\end{array}$ & $\begin{array}{l}\text { output } \\
\text { (catch) } \\
\text { (tons) }\end{array}$ & yield & $\begin{array}{l}\text { fishing } \\
\text { effort }\end{array}$ & $\begin{array}{l}\text { output } \\
\text { (catch) } \\
\text { (tons) }\end{array}$ & yield & $\begin{array}{l}\text { fishing } \\
\text { effort }\end{array}$ & $\begin{array}{l}\text { output } \\
\text { (catch) } \\
\text { (tons) }\end{array}$ & yield \\
\hline 1966 & - & - & - & - & - & $\rightarrow$ & - & - & - & - & - & - & 29913.7 & 72168.5 & 2.41 \\
\hline 1967 & 4958.0 & 19312.1 & 3.89 & 1514.0 & 4663.0 & 3.08 & 3538.0 & 5556.0 & 1.57 & - & - & - & 55483.0 & 118719.0 & 2.14 \\
\hline 1968 & 7312.0 & 27308.8 & 3,75 & 2623.0 & 5303.5 & 2.02 & 7017.0 & 11705.2 & 1.67 & - & - & - & 79069.0 & 198554.2 & 2.51 \\
\hline 1969 & 10012.0 & 25990.1 & 2.59 & - & - & - & 7289.0 & 7104.0 & 0.97 & 3800.0 & 8048.2 & 20.8 & 84148.0 & 177523.5 & 2.11 \\
\hline $66-69$ & 22282.0 & 72701.0 & 3.20 & 4137.0 & 9966.5 & 24.1 & 17844.0 & 24375.8 & 1.36 & - & - & 20.0 & 248631.6 & 566905.3 & 2.04 \\
\hline
\end{tabular}

1 unified trawling hours

2 yield (tous per unified trawling hour) 
Participation of particular ships of Polish factory fleet in fishing effort, yield and output (catch)

in ICNAF region for years 1966/69

\begin{tabular}{|l|c|c|c|}
\hline Type of ship & Fishing effort (\%) & Output (catch) (\%) & $\begin{array}{c}\text { Yield (tons per unified } \\
\text { trawling hour) }\end{array}$ \\
\hline B-15 & 63.7 & 61.5 & 2.20 \\
B-20 & 9.0 & 12.8 & 3.26 \\
B-10/14 & 8.7 & 7.2 & 1.89 \\
B-14 & 7.2 & 4.3 & 1.36 \\
B-18 & 6.2 & 8.8 & 3.20 \\
B-22 & 1.9 & 2.2 & 2.63 \\
B-23 & 1.7 & 1.7 & 2.41 \\
B-29 & 1.6 & 1.4 & 2.02 \\
\hline
\end{tabular}

average results for the whole ICNAF region for the years 1968 and 1969 in distribution to the types of Ship are presented in Tab. 8.

For both years, the lowest cost per $1 \mathrm{hr}$ of trawling indicate the ships B-15 and B-22 and the highest - B-23 and B-20, the difference exceeding twice the values. Similiar differences appear also in the costs of one ton yield in full relation.

It must be pointed out that the calculus of unit costs of fishing effort and of catches cannot be compared for the particular types of vessels and may be considered as indicative only. The more a vessel is industrialised, the higher part of the cost falls on subsequent production processes connected with preservation of the catches. These factors are however fully comparative in relation to the same types for different periods and different regions.

It must be underlined that the vessels type B-15 and B-22 in spite of highest industrialisation present the lowest factors of cost in relation to fishing effort and to the yield of 1 ton of catch.

Contrary to reservations relating to the costs. it must be admitted that the measure expressed by the ratio of landed catches to $1000 \mathrm{zł}$ of costs is fully comparative between all types of vessels (Tab. 8.)

Also in this case the bests results are obtained by the ships B-15 and B-22.

To verify the results obtained on the presented analyses of the materials for 1966-1969 mathematical analysis of the interdependence of the catches and of the effort was made.

The analysis was based on average data of the years of 1966-1969 without any consideration given to the seasonal character.

Assumed for analysis was the following equation of regression:

$$
\mathrm{y}=\mathrm{ax}+\mathrm{b}
$$




$$
\text { where } \begin{array}{ll}
\mathrm{y} & - \text { catches } \\
\mathrm{x} & - \text { trawling hours (unified units) } \\
\mathrm{a}, \mathrm{b} & - \text { parameters }
\end{array}
$$

\begin{tabular}{|c|c|c|c|c|c|}
\hline $\mathbb{B}-20$ & $\begin{array}{r}2.928 x \\
(0.319)\end{array}$ & $\begin{array}{r}+6.786 \\
(21.254)\end{array}$ & B-15 & $\begin{array}{r}2.100 \mathrm{x} \\
(0.252)\end{array}$ & $\begin{aligned}- & 8.058 \\
& (29.788)\end{aligned}$ \\
\hline B-14 & $\begin{array}{r}1.315 \mathrm{x} \\
(0.117)\end{array}$ & $\begin{aligned}+ & 0.994 \\
& (3.011)\end{aligned}$ & $\mathrm{B}-10$ & $\begin{array}{r}1.919 x \\
(0.399)\end{array}$ & $\begin{aligned}- & 0.983 \\
& (15.945)\end{aligned}$ \\
\hline B-18 & $\begin{array}{c}2.897 x \\
(0.139)\end{array}$ & $\begin{aligned}+ & 5.195 \\
& (3.609)\end{aligned}$ & & & \\
\hline
\end{tabular}

Basing on the data related to catches and trawling hours in years 1966-1969 (tab. 6), the following functions for particular vessel types were estimated:

Basing on the coefficient variants of particular equations, it is ascertained that the parameter $b$ is unessential in all equations. Thus the dependent of type is obtained, by:

$$
\mathrm{y}=\mathrm{ax}
$$

where:

the coefficient $\mathrm{a}$ is equal to the derivative

$$
a=f^{\prime}(x)=-\frac{y}{x}
$$

Since the output in unified units per 1 hour of trawling for the particular vessel types may be presented as follows:

$\begin{array}{llll}\mathbb{B}-20 & 2.928 & \mathbb{B}-15 & 2.100 \\ \mathbb{B}-18 & 2.897 & \mathbb{B}-10 / 14 & 1.920 \\ \mathbb{B}-22 & 2.665 & \mathbb{B}-14 & 1.315\end{array}$

For the remaining ship types, no equation could be estimated owing to too small statistical material.

According to the presented data it is ascertained that the verification of output in unified units per $1 \mathrm{hr}$ of trawling and for the years 1966-1969 is in sequence vessels complying with the empiric analysis; the calculation of unified trawling hours for fishing days gives the average of about 13 trawling hours for one fishing day. Considering an error of estimation and different method of calculation, the average of output on ICNAF region for the vessels above $1800 \mathrm{GRT}$, calculated in relation to unified trawling hours does not differ much from the output calculated acc. to the trend with eliminated seasonal oscillations as average monthly output, which amounts to $26 \mathrm{t}$ for each fishing day. This shows that for longer period for time the less exact method of output calculation according to the aggregated values for fishing days and more exact calculating method in unified trawling hours gives effectively the same results. 
Results of fishing operations of particular factory ship types in ICNAF region for years 1968-1969

\begin{tabular}{|c|c|c|c|c|c|c|}
\hline Type of ship & Years & $\begin{array}{l}\text { Fishing effort (unified } \\
\text { trawling hours) }\end{array}$ & $\begin{array}{c}\text { Assumed fixed cost per } \\
\text { one unified trawling } \\
\text { hour }\end{array}$ & $\mid \begin{array}{l}\text { Yield (tons per one } \\
\text { unified trawling hour) }\end{array}$ & Cost of one ton & $\begin{array}{l}\text { Value per } 1000 \mathrm{z} \\
\text { of cost }\end{array}$ \\
\hline$B-15$ & $\begin{array}{l}1968 \\
1969\end{array}$ & $\begin{array}{l}45072.8 \\
42004.8\end{array}$ & $\begin{array}{l}11380.2 \\
10663.4\end{array}$ & $\begin{array}{l}2.37 \\
2.17\end{array}$ & $\begin{array}{l}4807.7 \\
4903.1\end{array}$ & $\begin{array}{l}1743.0 \\
1766.0\end{array}$ \\
\hline$B-22$ & $\begin{array}{l}1968 \\
1969\end{array}$ & $\begin{array}{l}244.8 \\
2545.4\end{array}$ & $\begin{array}{l}11090.5 \\
11682.6\end{array}$ & $\begin{array}{l}2.39 \\
2.85\end{array}$ & $\begin{array}{l}4643.0 \\
4104.8\end{array}$ & $\begin{array}{l}1805.0 \\
2109.0\end{array}$ \\
\hline$B-10 / 14^{a}$ & $\begin{array}{l}1968 \\
1969\end{array}$ & $\begin{array}{r}8581.4 \\
10635.8\end{array}$ & $\begin{array}{l}13572.8 \\
10852.7\end{array}$ & $\begin{array}{l}2.49 \\
1.41\end{array}$ & $\begin{array}{l}5442.0 \\
7708.0\end{array}$ & $\begin{array}{l}1413.0 \\
1183.0\end{array}$ \\
\hline$B-14^{b}$ & $\begin{array}{l}1968 \\
1969\end{array}$ & $\begin{array}{l}7017.0 \\
7289.0\end{array}$ & $\begin{array}{l}17717.4 \\
16233.9\end{array}$ & $\begin{array}{l}1.67 \\
0.97\end{array}$ & $\begin{array}{l}10621.0 \\
16555.0\end{array}$ & $\begin{array}{l}852.0 \\
742.3\end{array}$ \\
\hline$B-18$ & $\begin{array}{l}1968 \\
1969\end{array}$ & $\begin{array}{l}6236.0 \\
7681.0\end{array}$ & $\begin{array}{ll}21 & 551.4 \\
20 & 021.7\end{array}$ & $\begin{array}{l}3.32 \\
2.97\end{array}$ & $\begin{array}{l}6495.4 \\
6742.6\end{array}$ & $\begin{array}{ll}1 & 189.3 \\
1 & 402.0\end{array}$ \\
\hline$B-20$ & $\begin{array}{l}1968 \\
1969\end{array}$ & $\begin{array}{r}7312.0 \\
10012.0\end{array}$ & $\begin{array}{l}25942.8 \\
18774.2\end{array}$ & $\begin{array}{l}3.75 \\
2.60\end{array}$ & $\begin{array}{l}6923.4 \\
7232.3\end{array}$ & $\begin{array}{l}1428.0 \\
1345.1\end{array}$ \\
\hline$B-23$ & $\begin{array}{l}1968 \\
1969\end{array}$ & $\begin{array}{c}2623.0 \\
-\end{array}$ & $\begin{array}{c}28140.7 \\
-\end{array}$ & $\begin{array}{c}2.02 \\
-\end{array}$ & $\begin{array}{c}13918.1 \\
-\end{array}$ & $\begin{array}{c}595.9 \\
-\end{array}$ \\
\hline$B-29$ & $\begin{array}{l}1968 \\
1969\end{array}$ & $\begin{array}{c}- \\
3980.0\end{array}$ & $\begin{array}{c}- \\
12136.1\end{array}$ & $\begin{array}{c}- \\
2.02\end{array}$ & $\begin{array}{c}- \\
6001.6\end{array}$ & $\begin{array}{c}- \\
1188.6\end{array}$ \\
\hline
\end{tabular}




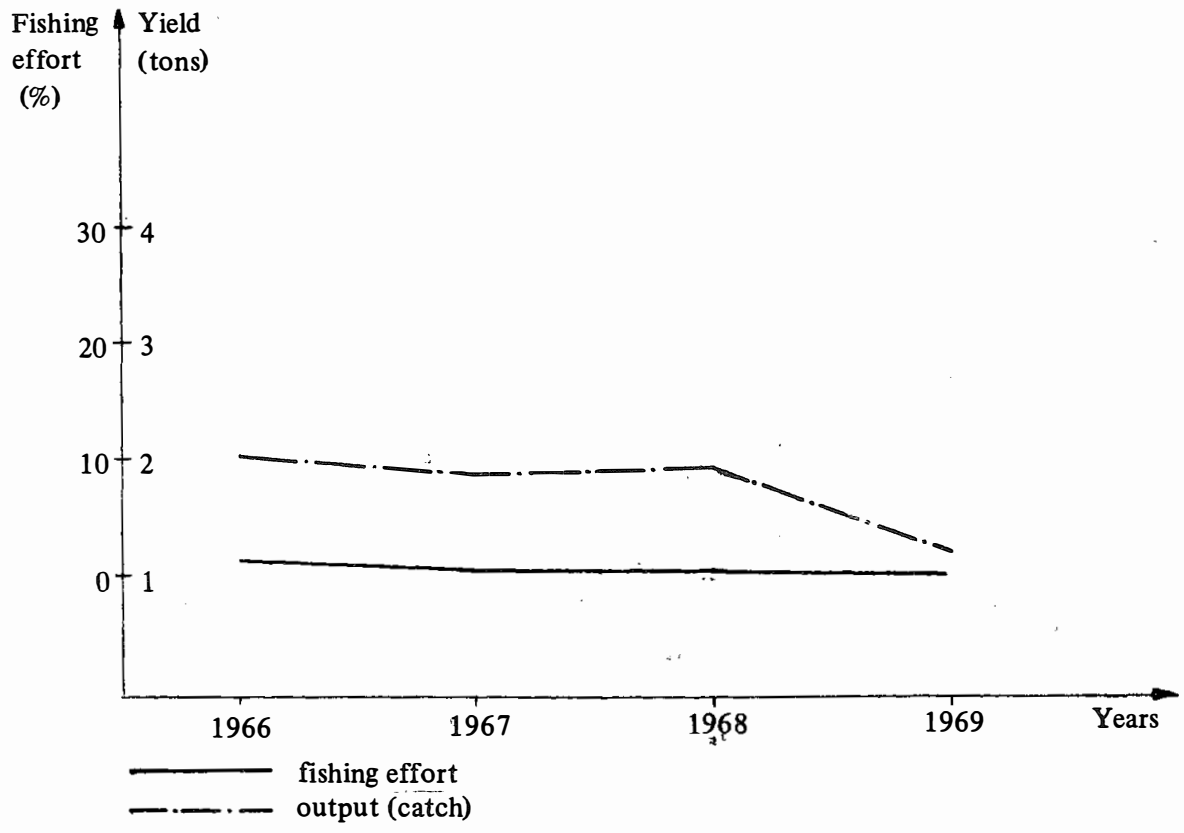

Fig. 5. Participation of fishing effort and output of Polish factory fleet in sub-region 1

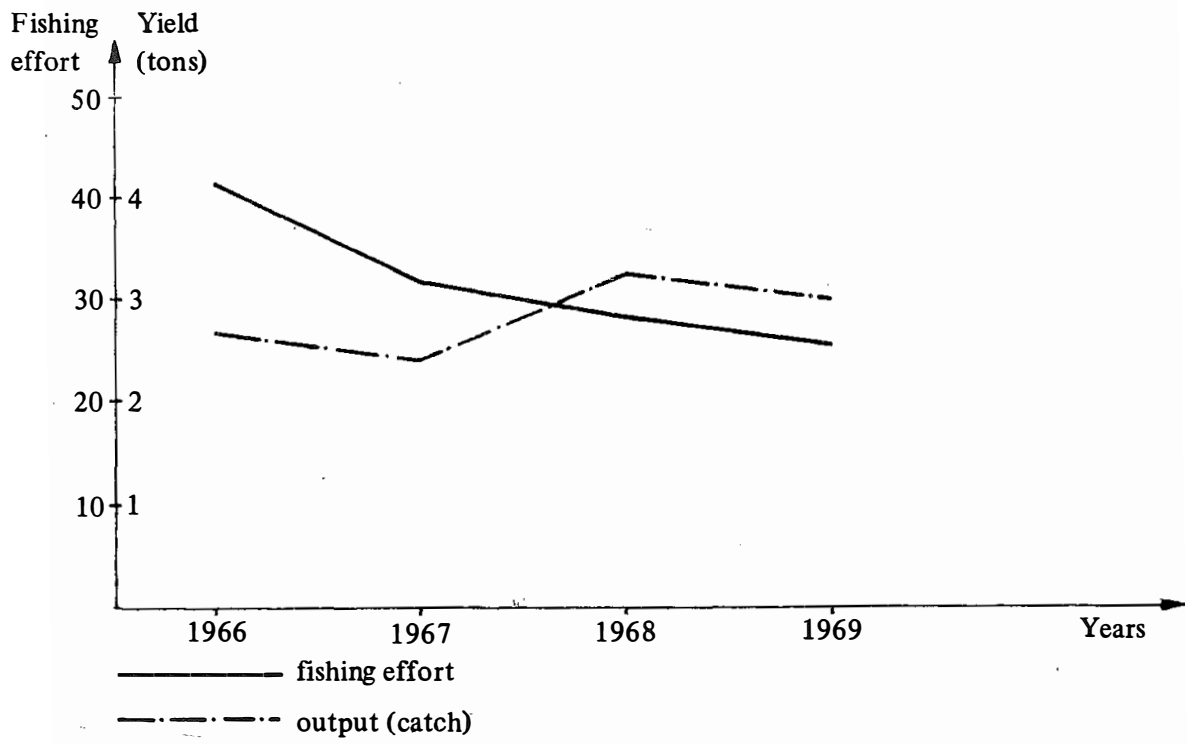

Fig. 6. Participation of fishing effort and output of Polish factory fleet in sub-region 2 


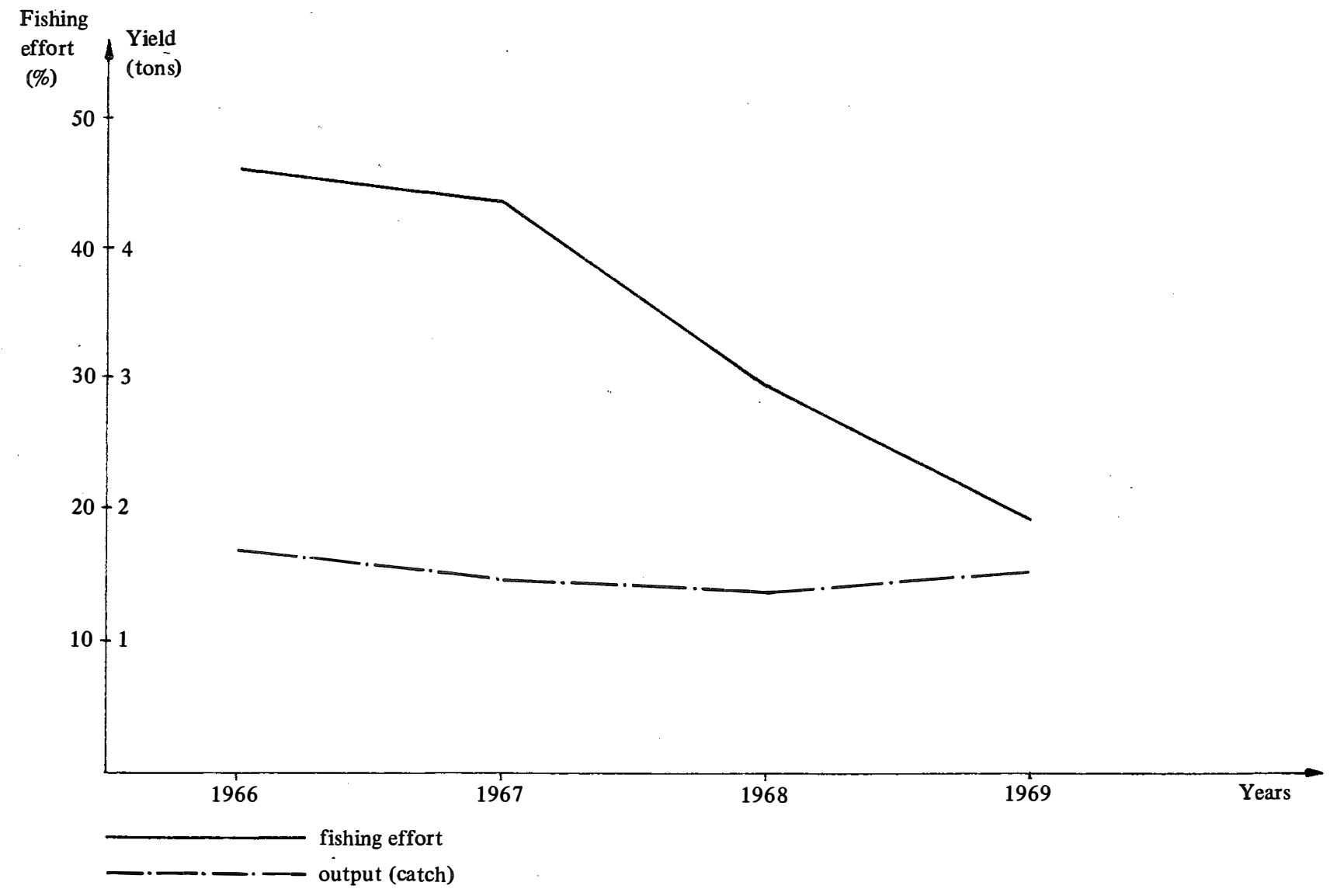

Fig. 7. Participation of fishing effort and output of Polish factory fleet in sub-region 3 


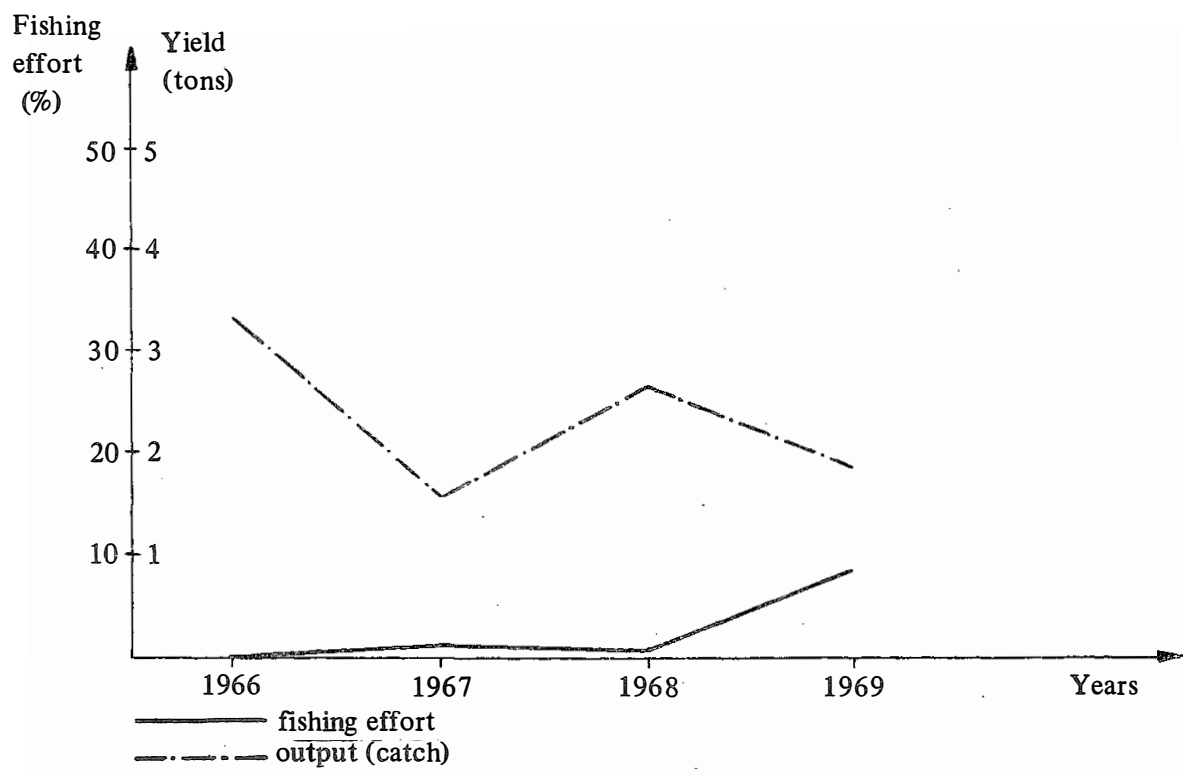

Fig. 8. Participation of fishing effort and output of Polish factory fleet in sub-region 4 .

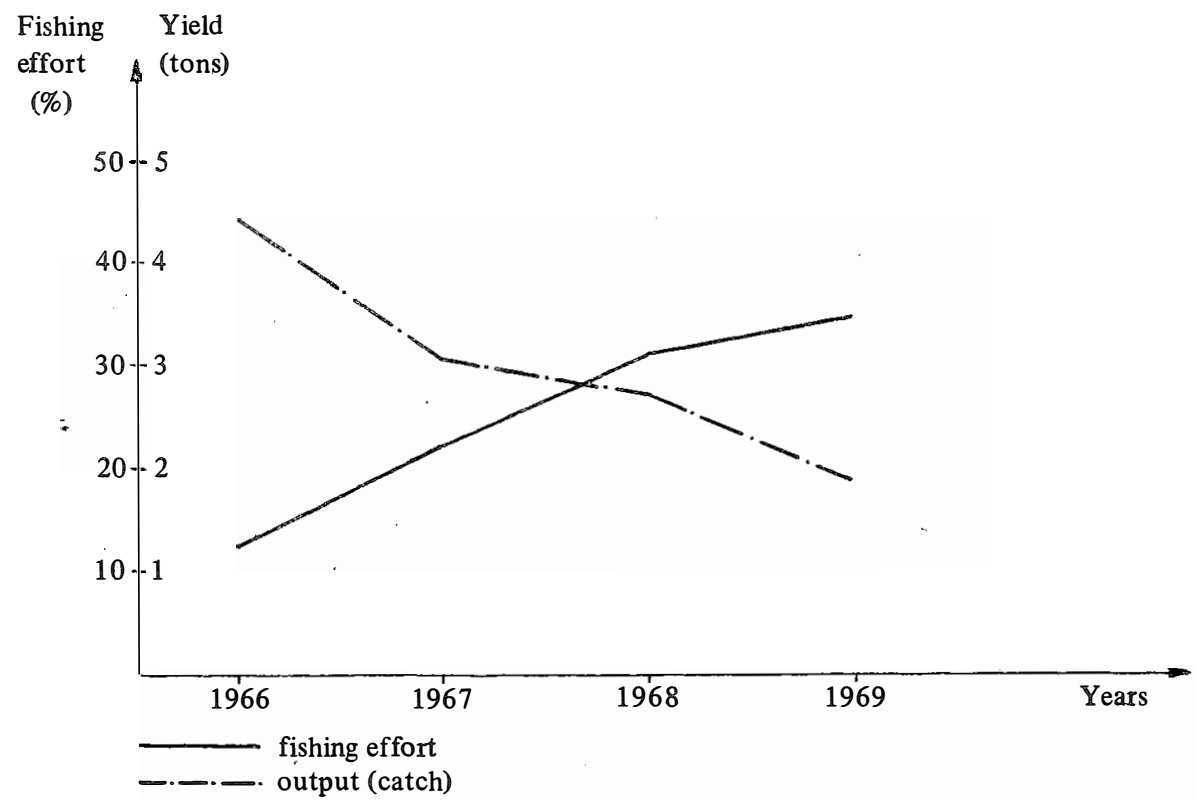

Fig. 9. Participation of fishing effort and output of Polish factory fleet in sub-region 5 


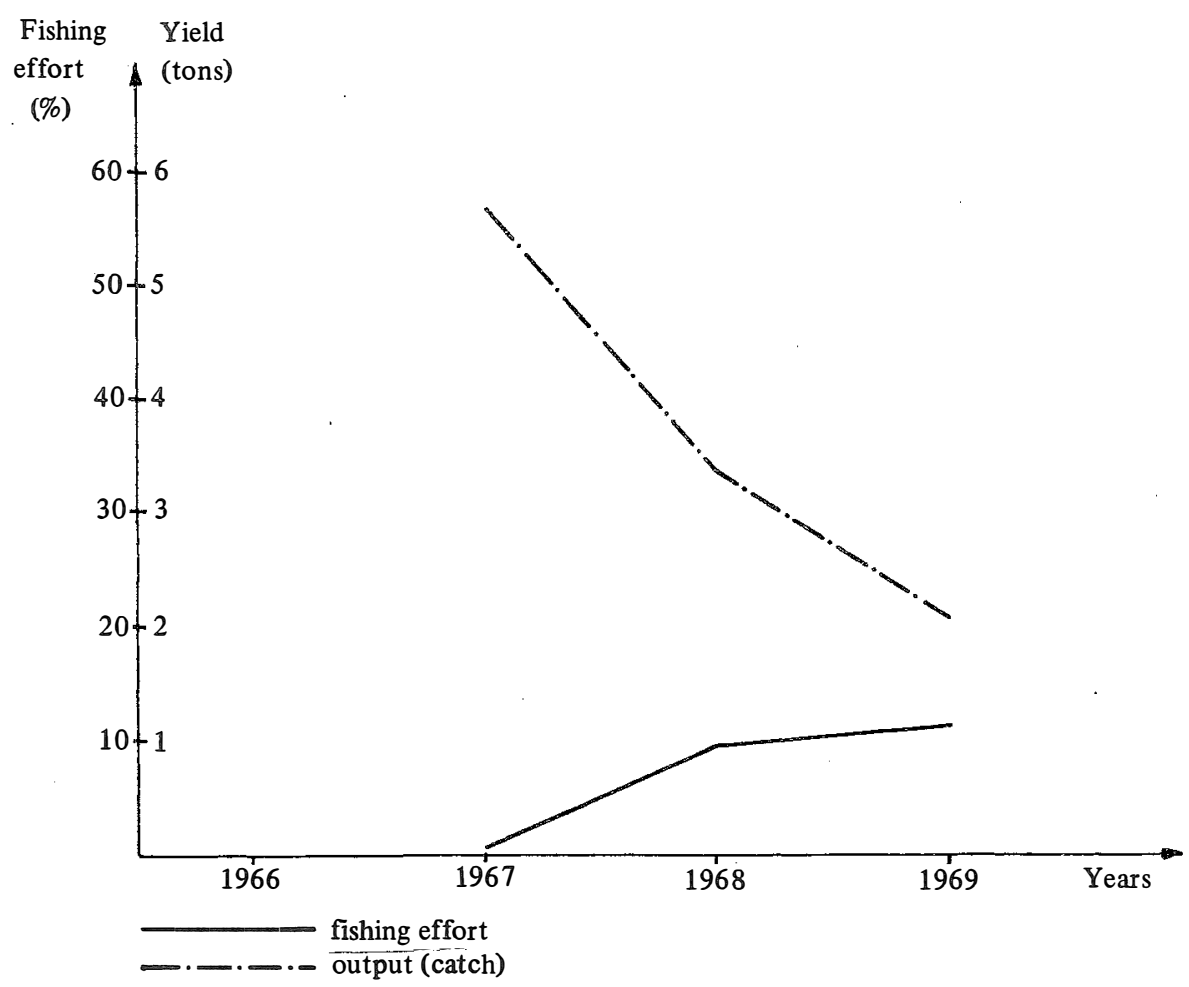

Fig. 10. Participation of fishing effort and output of Polish factory fleet in sub-region 6

\section{ASPEKTY EKONOMICZNE REGULACJI POÆOWÓW NA OBSZARZE ICNAF}

\section{Streszczenie}

Wobec wprowadzenia na łowiskach ICBAF-u pierwszych zarządzeń regulacji połowów, zaistniała konieczność sprecyzowania poglądów na efekty działalności polskiej floty rybackiej na tym obszarze. Przeprowadzając badania na powyższy temat zastosowano modele matematyczne i przeprowadzono estymację, które pozwalają ponadto na formułowanie prognoz połowów metodą analizy statystycznej.

Ocena tendencji występujących w procesie połowów wymaga zbadania czynnika sezonowości, które przeprowadzono w trzech kierunkach: sezonowości wydajności, sezonowości nakładu rybackiego i sezonowości połowów i wyładunków, jako funkcji dwóch pierwszych. Dla porównywalności nakładu rybackiego różnych typów statków podjęto próbę zastosowania jednostek ujednoliconych jako porównywalnej miary wyrażonej w 1 godzinie trałowania, w związu z czym wyznaczono obliczone w aneksie współczynniki korygujące, które uwzględniają typ statku, narzędzia połowów i rodzaj łowionych ryb.

Operując ujednoliconymi jednostkami nakładu rybackiego uzyskano porównywalne wydajności uzyskiwane w poszczególnych latach i podobszarach dla wszystkich typów statków. Otrzymane wielkości kosztów na każdym podobszarze posłużyły do wyprowadzenia kosztu 1 tony w relacji pełnej dla każdego podobszaru, typu statku i przedsiębiorstwa. 
Materiał źródłowy stanowiły publikage ICNAF-u pt. „Statistical Bulletin" oraz wyciagi 2 dzienników okrę towych wry stkich statków.

Dynamika stosunku rozmiaru połowów do nakładu rybackiego do r. 1968 nie wykazała wyraźnych objawów przełowienia na obszarze ICNAF-u jako całosici, aczkołwiek wysteppuje zaniejszenie się prayrostów krańcowych zgodnie 2 modelem krzywej asymptotycznej. Jednakze uwzqlędnienie wyników za lata 1969 i 1970 oraz połowów na podobsazze 6 wskazuje na to, że na niektórych obszarach połowy polskie zbliżają się do takiego poziom wydajności, te dalsze postępowanie nakładu mogłoby, w dotychezasowych warunkach biologicznych, wykazać objawy przełowienia niektórych gatunków.

Kształtowanie się wyników ekonomicznych w stosunku do wskaźników eksploatacyjnych potwierdza teze, że istnieje bardzo silna konelacja miedzy efektami ekonomicznymi a wydajnosicia łowisk. Wszystkie dokonane analizy wakazują na brak korelacji miedzy wydajnosciami na łowiskach a lokacja nakładu rybackiego, zarównow czasie jak i w rejonach połowowych.

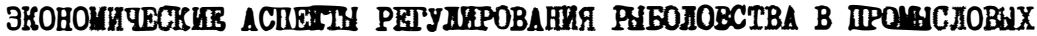 PAHOHAX UIEHA}

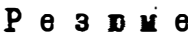

Ввиду осуществдения в промсловнх раионах икнеФ первнх ретенй по регудированио рњбодовства вознпкда необходпость упорядочендя отнотени и эфектаи деятедъности подьского рнбопромолового фдога в атои районе. ІІроводя иссдедовапия на вивеупомянуту эөчу, м исподьзовали математические модели и проведи статиствческур одевку, кочорне позводявт предсказывать прогнозы уловов по методу статистичөского анализа.

Оценка тенденция, набдодапщися в процессе дова, требует иссдедования Фактора сезонности, которое проводилось но трёи направдендя: сезонности пронзводительности, сөзонности затрат по добыче рнбн и сезонности уловов и выгрузки как функции двух первых. Для сравнения затрат по добыче рыбы судов раэного типа быти предприняты попытки исдользования унифицированных единид в качестве сравнитедьной церы иэмерения, вырахенной I часои траления, в связи с чеи были определены вычисленние в придохении корректируюцие козффициенты, которне учитыварт тип судна, орудия лова и вид вилавлкваекой рыбы.

Оперируя унифицированнчии единицами эатрат по добшче рыб, ме получили сравнительнур производительность, получаекур в отдельне годы и в отдельных подраћонах для всех типов судов. Полученные величины стомостей в каддом подрайоне бнли испольэовань для выведения стомости I тонны при поднои соохнотения для кахдого подрайон, типа судна и · предприятия. 
Источником послужили материалы ИКНАФ и выписки из судовых журналов. Динамика соотношения размера уловов и затрат по добыче рыбы до 1968 г. не проявила отчётливых тенденций к превышению норм вылова в промысловых районах ИКНАФ в целом, хотя и наблюдается уменьшение предельных приростов согласно модели асимптотической кривой. Однако.учёт результатов за 1969 и 1970 г.г., а также уловов в подрайоне 6, указывает на то, что в некоторых районах промысла польские уловы приближаются к такому уровню производительности, при котором дальнейшее увеличение затрат могло бы при существующи биологических условиях привести к тенденциям превышения норм вылова некоторых видов.

Формирование экономических эффектов по отношению к эксплуатационным показателям подтверждает положение о том, что существует очень сильная корреляция между экономическими эффектами и производительностью в промысловых районах. Все проведенные анализы указывают на отсутствие корреляции между производительностью в промысловых районах и размещением затрат по добыче рыбы как во время промысла, так и в его районах.

\section{Address:}

Praca wpłynęła w maju 1973 r.

Prof. dr hab. Andrzej Niegolewski

Insty tut Ekonomiki, Organizacji i Kierowania AR

71-550 Szczecin, ul. Kazimierza Królewicza 4

Polska - Poland 